\title{
MEDIATION AS A WAY TO ALTERNATIVELY RESOLVE CONFLICTS IN THE SOCIAL SPHERE
}

\author{
Rovenska V.V., Antonova V.I. \\ Donbass State Machine Building Academy \\ Ukraine, 84300, Kramatorsk, Akademichna str., 72 \\ rvv.ddma@gmail.com \\ ORCID 0000-0002-9412-878X, 0000-0001-8032-5718
}

Key words:

mediation, social sphere, conflict, mediator, structure of conflict, professional ethics, conflict interaction.
The article discusses the features of mediation as an alternative way to resolve conflicts in the social sphere. It has been found out that the conflict interaction in the professional activity of social specialists covers psychological, humanitarian, legal and communicative aspects. It has been proved that mediation can provide a quick solution to disputesat the lowest cost through processes specially adapted to the needs of the parties. The interconnections of the substantive structural elements of conflicts in the social sphere have been analysed. The principles and stages of mediation are presented. It has been determined that mediation is the most favourable way to resolve conflicts in modern conditions; it helps to develop mutual understanding and reach a new level of mutual trust. The mediation can be seen as an additional and effective mechanism for the protection of human rights and the maintenance of law and order in society. The mediation can provide the quickest resolution of disputes through processes that are tailored to the needs of the parties. In addition, there is a greater likelihood that the agreements reached in the mediation process will be voluntarily adhered to, and friendly and lasting partnerships will continue to be maintained between the parties. Such advantages are becoming increasingly apparent and effective in situations of, inter alia, an international nature between business entities. It has been found that it is advisable for future social experts to prepare for the provision of mediation services in conflict resolution, as is done in a number of foreign countries. The basic principles of public mediation can be defined by careful preparation, which involves the analysis of the conflict, the study of the cultural, social, historical features of the countries, society, communities involved in the conflict; the consent of the parties and the willingness to take responsibility for the decisions made; the legal field of official mediation; mediator impartiality and privacy. In public mediation, it is not always possible to adhere to the principle of the independence of the mediator, especially in cases where states or international organizations act as mediators. It is also difficult to make the process confidential, especially in the current development of information technology.

\section{МЕДІАЦІЯ ЯК СПОСІБ АЛЬТЕРНАТИВНОГО РОЗВ'ЯЗАННЯ КОНФЛІКТІВ У СОЦІАЛЬНІЙ СФЕРІ \\ Ровенська B.B., Антонова B.I.}

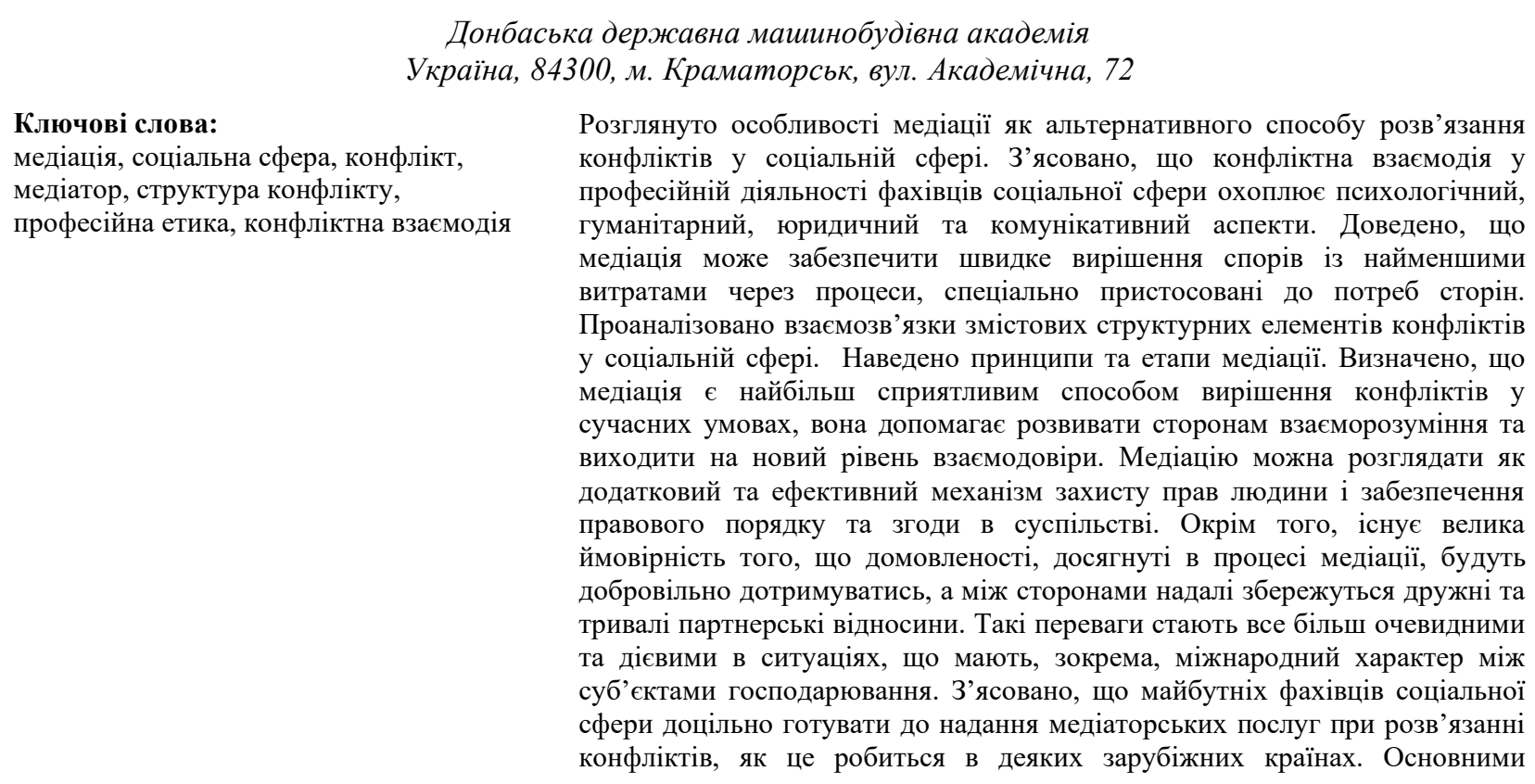


засадами публічної медіації можна визначити ретельну підготовку, що передбачає аналіз конфлікту, вивчення культурних, суспільних, історичних особливостей країн, суспільства, громад, що залучені до конфлікту; згода сторін та готовність брати на себе відповідальність за прийняті рішення; правове поле проведення офіційної медіації; безсторонність медіатора та конфіденційність. У публічній медіації не завжди вдається дотримуватися принципу незалежності медіатора, особливо у випадках, коли посередниками виступають держави чи міжнародні організації. Також важко зробити процес конфіденційним, особливо на сучасному етапі розвитку інформаційних технологій.

\begin{abstract}
Statement of the problem
Conflicts are an integral part of the life of everyone, society and states. They can contribute to the development of these entities, and can lead to a deterioration of relationships and cause permanent damage in the form of material and human loss. The outcome of the conflict depends on the attitude and behaviour of the subjects in it. Conflicts are perceived as an inevitable phenomenon that needs to be studied not only, but also to be actively influenced in order to prevent negative consequences and to realize constructive possibilities of conflict interaction. At the present stage of society's development, attempts are being made to develop such methods of conflict resolution that would reduce or avoid harm and promote further development. One such method is mediation, as a way of resolving a conflict involving a third party neutral or party that will facilitate communication between the parties to the dispute and reach an agreement.
\end{abstract}

\section{Analysis of recent studies and publications}

In recent years, the issue of conflict resolution in collectives has begun to gain broader discussion. This issue was investigated by both domestic and foreign scientists, including LM Emelianko, V.M. Petlyukh, L.V. Torgova, A.M. Grinenko [1], O.V. Vinoslavskaya [2], I.V. Kalinkina [3], L.E. Orban-Lembrick [4], N.V. Grishina [5], G. Prokopenko [6], S. Anthony, M. Johnson, J. Sinfield, E. Altman [7] and others.

They considered the causes of conflicts in different teams, including creative ones, depending on their temperature, nature, lifestyle and other reasons. Problems and prospects of formation and development of alternative ways of solving social conflicts, in particular mediation, is a topical topic of research of domestic and foreign scientists, practitioners-representatives of different spheres of human activity (lawyers, psychologists, educators, political scientists and others). It is worth noting that with the adoption by the Verkhovna Rada of Ukraine in 2015 as the basis of the draft law "On Mediation", the amount of scientific research has increased significantly. In particular, it is necessary to turn to scientific researches in the field of alternative solution of conflicts of such scientists as: N. Bondarenko-Zelinskaya, S. Zagainova, S. Zapara, G. Goncharov, O. Karmaz, V. Komarov, D. Kusherets, S. Kuzmenko, N. Mazaraki, J. Mirimanoff, Y. Pritika, V. Pukhalenko, E. Runesson, N. Thurman, V. Reznikov, S. Fursa, V. Yarkov and others. Recently, in our country, more and more information is emerging about mediation, which has a fairly widespread practice in Western countries and is of interest to the public of Ukraine. Although, according to some experts, mediation in Ukraine is still "a phenomenon unknown and mysterious" [8], but it is gradually gaining pace and popularity.

\section{Objectives of the article}

The purpose of the article is to identify the structural and functional aspects of mediation as an alternative way of resolving conflicts in the social sphere.

\section{The main material of the research}

In the process of professional training of future specialists in the social sphere, it is very important to teach independent activity, determined by the mobility of thinking during the resolution of conflicts in professional activity. In this context, the potential of higher education institutions for quality education is becoming the leading and determining competitiveness of future professionals.

Therefore, modern education acts as "a means of acquiring a high social status, a social filter, and at the same time has the goal of self-development, self-realization, selfsatisfaction of the individual, only when perceived in the unity of the target and indirect parties and gives the opportunity to harmoniously enter into the context constructive interaction with other people" [9 p. 34]. Therefore, it is undoubted that the humanistic dominant in conflict resolution should be present in the professional training of future specialists in the socio-economic professions.

Today, in our country, social policy should be implemented by specialists who have a high level of professionalism and are ready for professional activity in general and for resolving professional conflicts in particular. As proof of the validity of such a thesis, we will cite the following facts: firstly, according to the Order of the Ministry of Social Policy "On approval of the State standard of social service of mediation (mediation)" of August 17, 2016 [10], a future specialist should be able to provide expert assistance in conflict/dispute resolution as mediator; secondly, the School Conflict Resolution Program [11] is currently being implemented in general educational institutions, which solves the problem of primary prevention of offences and correction of students' deviant behaviour on the basis of mediation. There is a certain dialectical relationship between the opposing functions of conflict. Both sides program them: first, the positive effects of the conflict, and the enemy, the negative. Moreover, the benefits for oneself before the conflict are seen only in causing maximum harm to another. But in reality, in both cases, the consequences of the destabilizing and destructive functions of the conflict are exposed to both sides. Fig. 1 presents the interconnections of the substantive structural elements of conflict in the social sphere. 
Psychological perspective

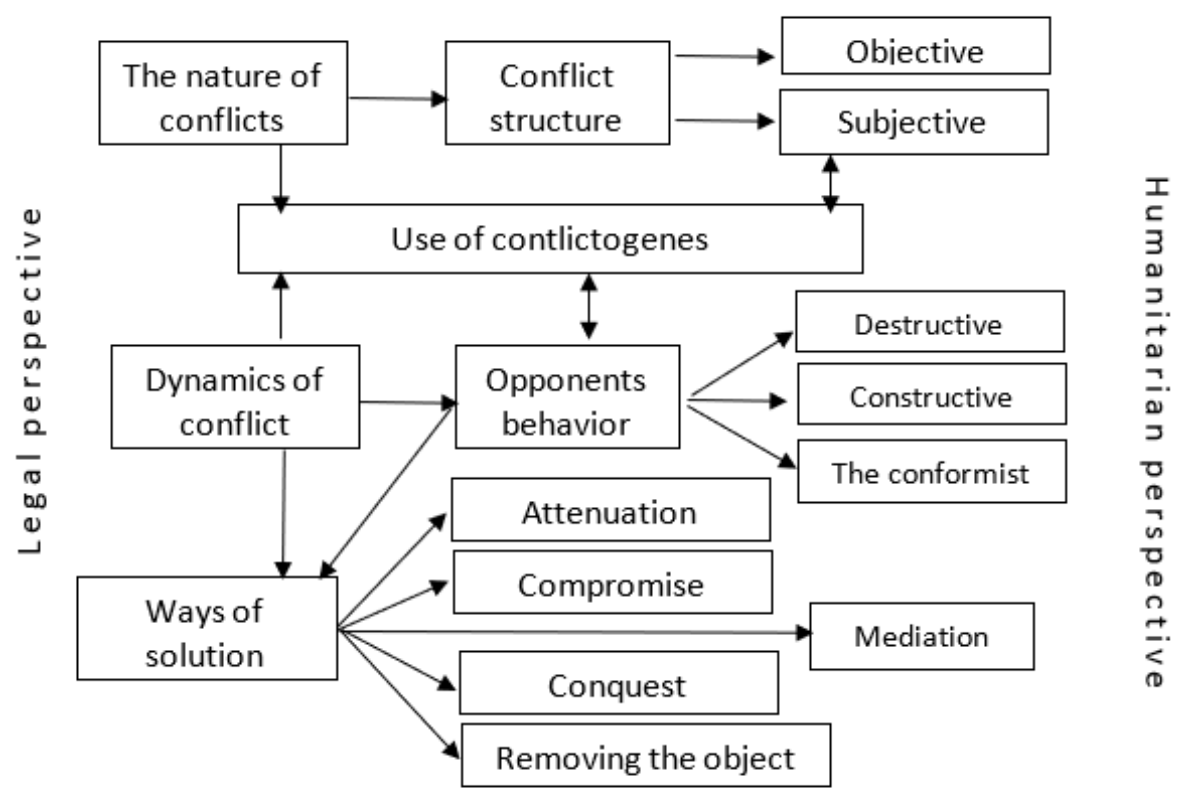

Communicative perspective

Fig. 1. The Relationships of the Content Structural Elements of Conflict in the Social Sphere [Developed by Source 12]

The mediation, as a method of conflict resolution, involves participation in a third party (not the subject of the conflict) process that facilitates communication and agreement between the parties to the conflict. In the general sense, "mediation" (from Latin mediatio mediation, middle ground), entrenched in the second half of the 20th century, is the process of negotiation between the parties with the participation of a neutral third party, the mediator, in order to find a mutually beneficial solution.

Mediation is understood as a voluntary and confidential process, skilfully prepared by an independent and neutral person who, by helping the conflicting parties to deal with the conflict, promotes consensus and understanding between the parties. Mediation allows participants to identify the causes and peculiar "acute angles" of a dispute, reduce communication barriers, develop proposals and solutions, and enter into a mutually agreeable agreement, if the parties agree. The success of mediation as an effective way of resolving conflicts depends largely on the professionalism of mediators and their high level of professional ethics. It is also important that the parties to the conflict are aware of the importance of maintaining further relations on the basis of understanding and consensus. Only in such conditions will the interaction and the effectiveness of the mediation process be effective for all its participants. It is very important to consider it as a conflict-destroyer (a source of violence) and a conflict-creator (a source of development) at the same time when resolving a conflict. Mediators, working with conflict, play a third role: mediator, transforming conflict, avoiding violence and promoting development (Fig. 2).

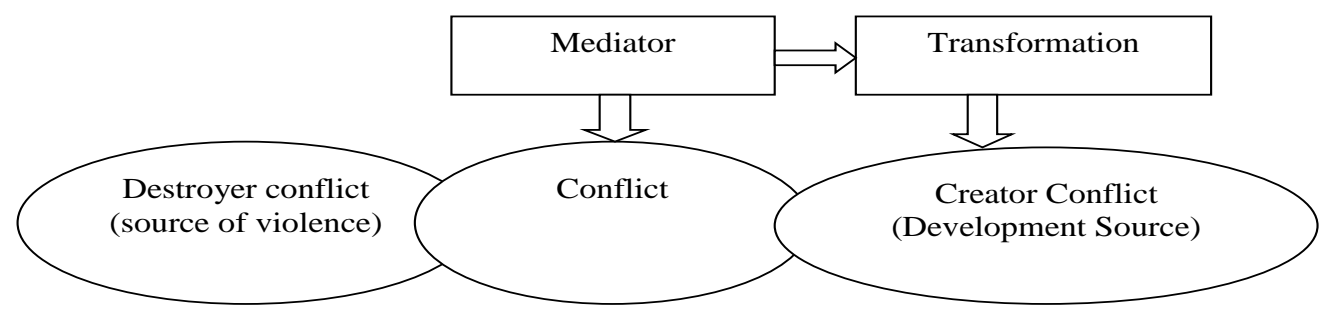

Fig. 2. The role of the mediator in the conflict

If we recognize that conflict can be both a source of destruction and a source of development, then the transformation of the conflict must act in such a way that the creative aspects dominate. It is more than just directing the conflict away from violence. This is the direction of the conflict in the development - both the humanitarian development of its individual participants, and the social development of the collective members, as well as world development in general.
Conflict has its negative and positive manifestations and consequences. And how a person treats the conflict and how he perceives it depends on his solution. In order to resolve the conflict, it is also important to understand that it is not the problem itself, but our behaviour before, during and after it. In order to resolve the conflict positively, it should not be feared, but must be able to be resolved peacefully. People often perceive conflicts as obstacles, danger, destructiveness and pain. Therefore, most people want to avoid conflict. 
However, conflicts need to be viewed in another, more appropriate way: they are an important signal that something is (already) in order and needs to be changed; it is a chance to develop and improve relationships. This chance is used depends on how to approach the conflict. Destructive ways of resolving a conflict include all those who lead to aggravation of relationships and do not contribute to the search for a positive solution to the conflict issue. Often, differences between people turn into personal conflict. Different perspectives on certain problems turn into reproaches to others and judgments about their character, intentions and motives. Instead of considering a common problem, consider another person as a problem.

Constructive ways, on the contrary, promote mutual understanding and the search for positive ways to resolve the conflict. Constructively resolving conflicts means finding a solution to the problem without affecting the opponent's personality. All parties to the conflict jointly take responsibility for the problem and look for a solution side by side. The process of constructive conflict resolution brings satisfaction to both parties and improves their relationship.

Eight principles have been the basis for resolving the conflict peacefully in a constructive way (developed by the Foundation for Peace and Future Research in Sweden):

1. People: separate the person from the problem - discuss the problem, not each other.

2. Interests: Focus on interests, not positions.

Table 1 - Comprehensive overview of the phenomenon of conflict and how to resolve it [developed by author based on source 13]

\begin{tabular}{|l|l|l|}
\hline Component 2 & Component 1 & Component 3 \\
\hline Causes and conditions of conflict & Latent conflict & $\begin{array}{l}\text { Conflict Intervention: Third Party } \\
\text { Goals }\end{array}$ \\
\hline Individual level Social level & Parties & Conflict prevention \\
\hline International level & Problems & $\begin{array}{l}\text { Conflict management } \\
\text { Conflict resolution } \\
\text { Conflict resolution } \\
\text { Conflict transformation }\end{array}$ \\
\hline $\begin{array}{l}\text { Global / Environmental } \\
\text { level }\end{array}$ & Objectives & $\begin{array}{l}\text { Three-step approach } \\
\text { Competition or collaboration } \\
\text { Negative or positive world Model-1 } \\
\text { or Model-2 }\end{array}$ \\
\hline
\end{tabular}

Conflict (Component 1)

Concerning the conflict - latent (hidden) or growing or aggressive - professionals and potential third parties would like to know more about: (a) the parties; (b) issues that cause conflicts between the parties; (c) the goals they hope to achieve; (d) the means used to achieve these objectives; (e) their conflict orientations and approach to conflict resolution; (e) the nature of the conflict environment and the means of resolving it.

Parties

The first and most obvious question that comes to mind in relation to any particular conflict is: "Who is the party to the conflict?" regions. It is important for conflicting analysts and potential third parties to keep in mind that the
3. Options: look for mutually beneficial options.

4. Criteria: The result must meet the mandatory criteria.

5. True: There are several truths: yours, theirs, and maybe someone else's.

6. Means: keep track of the unity of means and goals

7. Preconditions: Only pursue goals that are appropriate for both you and the other party.

8. Power: Achieve your goals, not punish others [13].

It must be assumed that conflicts do have many common components, because in industrial relations, international relations, interpersonal relations, and even animal life, they do not differ from each other, and it is worth finding a common element. Finding the "common element" is possible on two levels: macro-levels, when using the deduction provides a basis for organizing information throughout the area of conflict analysis and its resolution, and micro-levels, where there is a potentially useful basis for systemising information in any particular conflict. In Table 1 we can find in the centre the conflict (Component 1), its causes and conditions (Component 2) - on the left and the intervention in the conflict (Component 3 ) - to the right of it. Thus (and in any case), it is clear that the focus is on conflict, and our main "subject of study" is the phenomenon of conflict, which we must explain or anticipate in order to effectively respond through its prevention, management, and settlement, solution, transformation or solution. involvement of many parties represented as "others" should be discussed with client parties (if intermediaries are "outsiders") or executives (if intermediaries are "insiders") prior to the conclusion, important agreements. The principles of face-to-face negotiation are what you need to have dealt with all parties before such agreements are concluded and / or implemented.

It is also important to investigate the extent to which the conflict in question is related to other conflicts. Because it will be difficult to resolve it effectively if the parties / parties to the conflict have their own internal conflicts.

Causes and Conditions of Conflict (Component 2) 
Given the complexity of the conflict due to its causes and conditions, professionals and potential third parties need to learn about the potential sources of conflict, working at the following levels: (a) individual (biological, physiological, psychological); (b) public (political, economic, social); (c) international; and (d) global / environmental. Regardless of the level of conflict (interpersonal, intergroup, inter-organizational, or international), management factors at each of these four levels influence the conflict (depending on the level at which it arose). And if the causes and conditions of the conflict are multilevel, then the intervention in the conflict must also be carried out at these levels [13].

\section{Conflict Intervention (Component 3)}

Before engaging in a conflict, different types of potential third parties - activists, lawyers, researchers, mediators (coaches), law enforcement officials - must have a clear understanding of their goals, which may include any or some combination of the following: a) (violent) Conflict Prevention: Stop the deployment of the conflict (e.g. UN Preventive Force in Macedonia [UNDP]); b) Conflict management, conflict prevention (for example, the UN Mission in Bosnia [UNCCD]); c) conflict resolution: end the conflict, if necessary, with the use of force (for example, NATO bombed Bosnian-Serb positions in August-September 1995; NATO missions - NATO-led
Stabilization Force [IFOR] and Stabilization Force in Bosnia [SFOR]); d) Conflict resolution: to influence the causes and conditions underlying the conflict ("what contributes to the conflict's unfolding"); e) conflict transformation (prevention): the need to work with longterm relationships between survivors and their "neighbours" so that they "use" less lethal means during the conflict than during the deployment period (for example, the European Union [EU] aims to go beyond a narrow understanding of the sovereignty or nationalism of the state system and to move towards a common security ["warning"]) [13]. Professor Johann Galtung believes that conflict, like organic forms, has its own life cycle. It arises, reaches an emotional, even violent, climax, falls, disappears and often arises again. This is logical: individuals and groups (nations, states, etc.) have goals; goals may be incompatible, exclude each other; when goals are incompatible, there is a problem, a contradiction; any person or party with unfulfilled goals feels frustrated and dissatisfied; the more fundamental goals (for example, basic needs and interests), the stronger these feelings; frustration and dissatisfaction can provoke aggression by altering the abused internal attitude or outward behaviour in the form of violence. Thus, conflict can have eternal life, irritating and damaging, disappearing and reemerging.

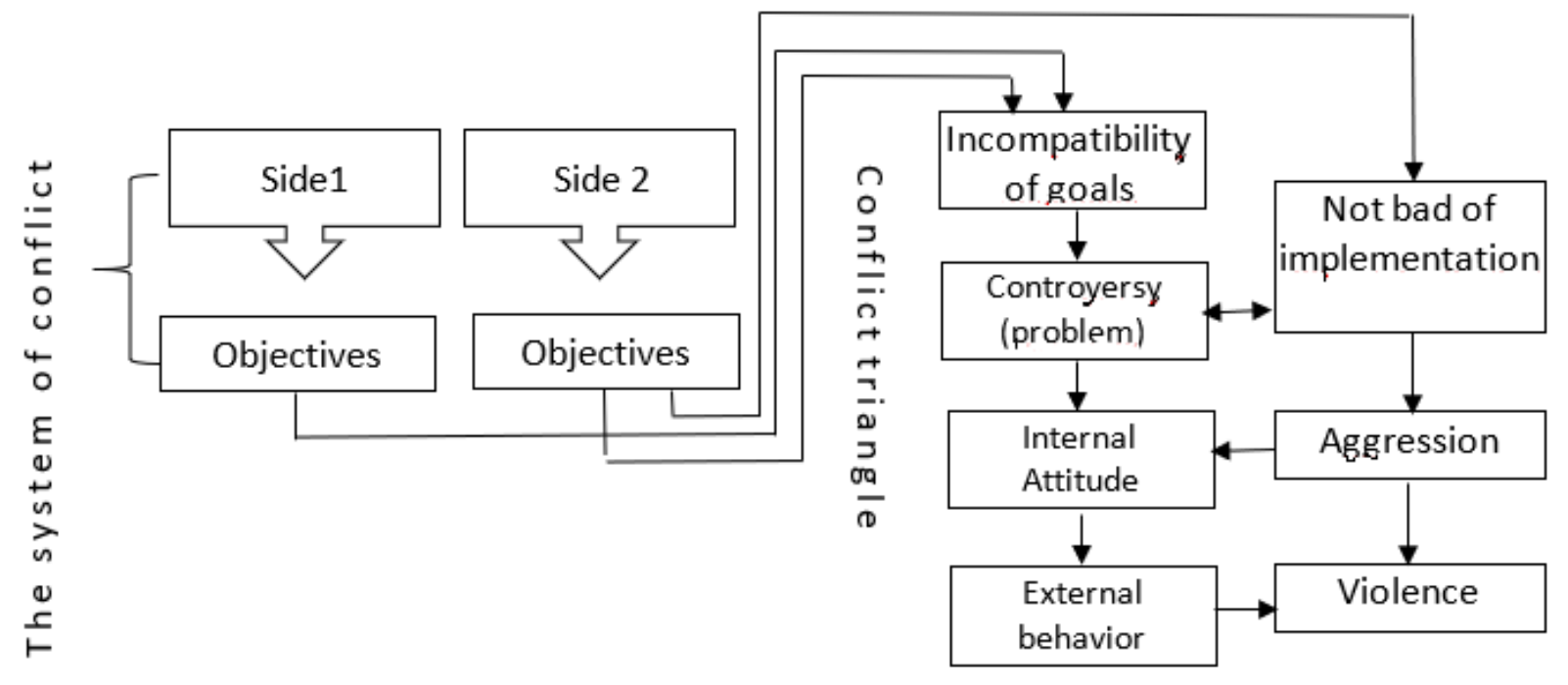

Fig. 3. Conflict Structure [Developed by Source 13]

Conflict has parties and parties have goals. When goals are incompatible, there are controversial issues with relevant attitudes and behaviours. The overall result of all this is a conflict. A mediator is a specially trained mediator in conflict resolution who equally supports both sides and helps them find a mutually acceptable solution.

The mediator facilitates the parties' communication process, helps them to understand their positions and interests more deeply, and seeks effective solutions to the problem, enabling the parties to reach an agreement. The functions of the mediator are intended to assist the parties in counter-active behaviour to understand the common meaning of the problem, to desire to work on the problem and to find the best ways to solve it. Mediation is the most conducive way to resolve conflicts in today's context: orientation of the mediation procedure to the interests and needs of the parties; during mediation the parties remain the "owners" of their conflict and retain control over the process of its settlement; working out and making a decision that is in the interests of the parties to the conflict depends on them; mediation is based on a human-centred approach; mediation allows to resolve the conflict without imposing strict obligations on the parties; mediation allows the parties to find a solution to the conflict at the "win all" level; mediation helps to develop the parties of mutual understanding and to reach a new level of mutual trust; negotiations are more successful when the parties to the conflict have to continue their relationship after the conflict than when they have no relationship with each other afterwards; parties to the conflict communicate directly, not through their representatives (lawyers, legal advisers), and therefore do not lose control of the process; 
mediation can save the parties time and money (compared to litigation); mediation enables people to complain in a safe atmosphere. Axiomatically, the hidden driving forces - motivations, fears, interests - are blocked before mediation begins; the ability to listen when people talk about conflict gives a great opportunity to unlock these forces; The neutral, trusting and non-therapeutic nature of mediation sessions encourages her to participate.

The mediation process develops the ability to negotiate, which is useful for resolving conflicts in the future. Principles of mediation:

1) Volunteering. The mediation procedure is purely voluntary. No one can force outsiders to use mediation or at least try to do so.

The mediation is a voluntary process based on the willingness of the parties to reach a fair and just agreement. Volunteering is manifested in the fact that: neither party can be forced to participate in mediation; each participant can leave the mediation process at any stage; consent to the outcome of the mediation process is also purely voluntary; the parties themselves control the progress and results of mediation; mediator services are voluntarily accepted by both parties throughout the procedure.

2) Impartiality. The mediator must always act in a completely objective way with respect to each of the parties, carry out his work objectively and honestly, and mediate only those cases in which he can remain impartial and fair. The mediator is neutral with respect to the conflict.

3) Privacy. The mediator must keep confidential all the information received during the mediation. Any information privately disclosed to a mediator by one of the

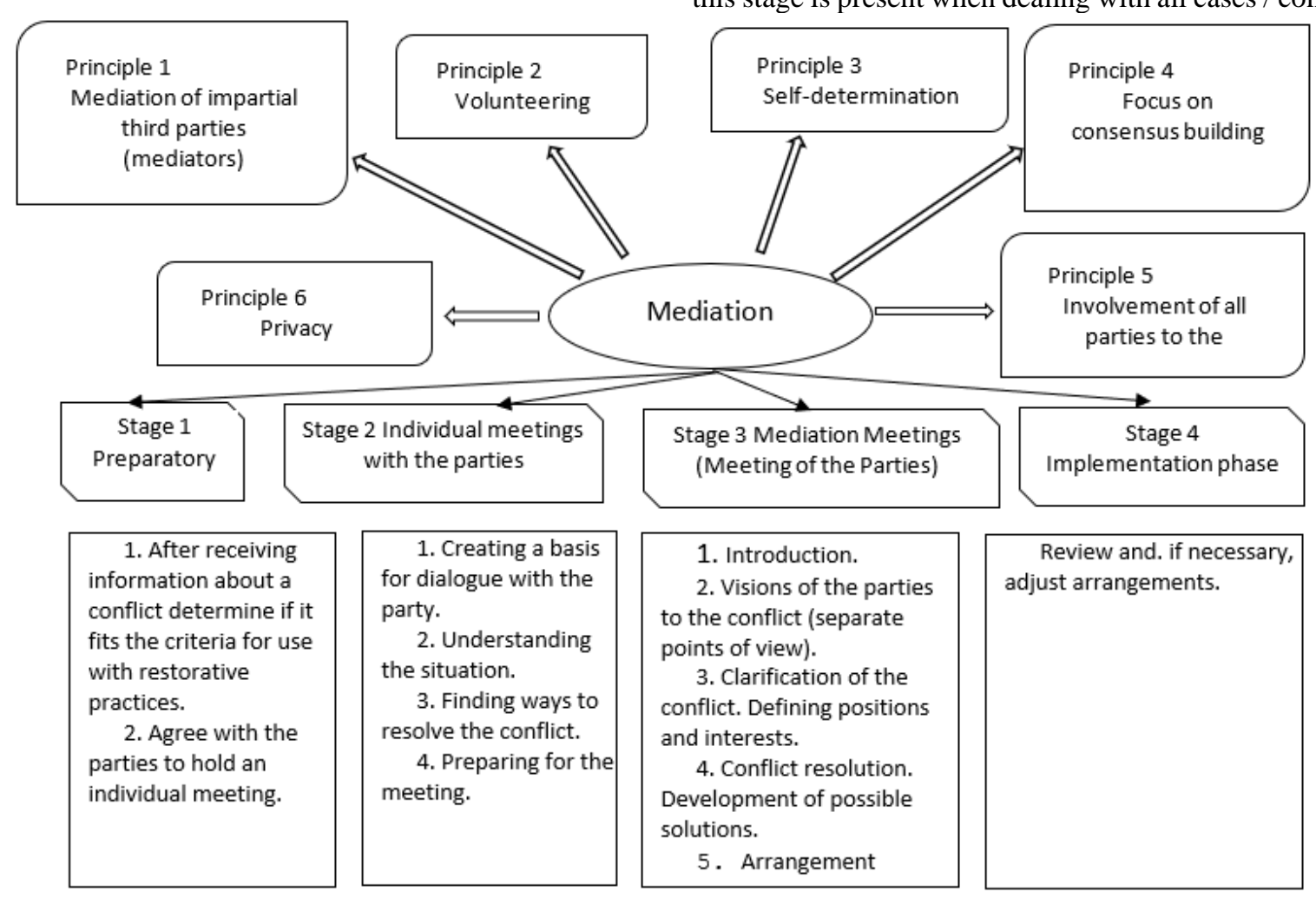

parties shall not be shared with the other party, unless the consent of the other party so requires or is required by law.

4) Allocation of responsibilities. The process of mediation is characterized by the fact that the parties to the conflict themselves, by voluntarily participating in the mediation procedure, produce possible solutions to the problem. The mediator does not make, take or impose any ready-made decisions on them. He leads and directs the process of interaction between the parties, creating the conditions for better understanding of the disputants both themselves and each other. The process of mediation has its stages, rules and structure, the adherence of which allows the mediator to successfully conduct mediation. Principles and stages of mediation of ideas (Fig. 4).

Each stage has its purpose, objectives and content. The following is a step-by-step model of mediation in its socalled classic version, when the mediator and the parties go through all the proposed steps to resolve the conflict. However, it should be noted that adherence and consistency of each stage depends on the content and complexity of the conflict, its typology, structure, stage of development, the strategy of the parties, the urgency of the solution, the composition of the parties / parties to the conflict (levels of involvement of participants in the conflict (3D map) etc.

For example, in an institution of a student-student conflict, most mediation may begin immediately from stage 3 of the Mediation Meeting (Meeting of the Parties). It can be said that productive individual meetings with the parties are the key to successful completion of the most difficult stage of mediation - a direct meeting of the parties. The preparatory stage should not be underestimated. It is critical to determine whether a case / conflict is a criteria for dealing with restorative practices. And in this format, this stage is present when dealing with all cases / conflicts.

$$
\begin{aligned}
& \text { 2. Visions of the parties } \\
& \text { to the conflict (separate } \\
& \text { points of view). } \\
& \text { 3. Clarification of the } \\
& \text { conflict. Defining positions } \\
& \text { and interests. } \\
& 4 \text {. Conflict resolution. } \\
& \text { Development of possible } \\
& \text { solutions. } \\
& \text { 5. Arrangement }
\end{aligned}
$$

Fig. 4. Principles and stages of mediation [developed by the author based on source 13] 
Thus, mediation is understood as a voluntary and confidential process, skilfully prepared by an independent and neutral person who, by helping conflicting parties to deal with the conflict, promotes agreement and understanding between the parties. The mediation allows participants to identify the causes and peculiar "acute angles" of a dispute, reduce communication barriers, develop proposals and solutions, and enter into a mutually agreeable agreement, if the parties agree.

The success of mediation as an effective way of resolving conflicts depends largely on the professionalism of mediators and their high level of professional ethics. It is also important that the parties to the conflict are aware of the importance of maintaining further relations on the basis of understanding and consensus.

Only in such conditions the interaction and the effectiveness of the mediation process will be effective for all its participants.

The mediation can be seen as an additional and effective mechanism for the protection of human rights and the maintenance of law and order in society. Mediation can provide the quickest resolution of disputes through processes that are tailored to the needs of the parties. In addition, there is a greater likelihood that the agreements reached in the mediation process will be voluntarily adhered to, and friendly and lasting partnerships will continue to be maintained between the parties.

Such advantages are becoming increasingly apparent and effective in situations of, inter alia, an international nature between business entities.

\section{Conclusions}

It is determined that the conflict in the professional activity of a specialist in the social sphere is a mismatch of opinions, views, needs and positions of the subjects of conflict opposition regarding the fulfilment of functional duties and organization of interpersonal interaction that takes place in the horizontal and vertical plane in the social sphere, services.

The conflict interaction in the professional activities of social sphere professionals encompasses psychological, humanitarian, legal and communicative perspectives. The leading tendency of professional training of future specialists in the social sphere is the introduction of dual specialty programs in order to promote academic collegiality and the implementation of interdisciplinary cooperation and to establish constructive relations between people through the development of pragmatic decisions in the resolution of individual and global conflicts.

It has been found that it is advisable for future social experts to prepare for the provision of mediation services in conflict resolution, as is done in a number of foreign countries. The basic principles of public mediation can be defined by careful preparation, which involves the analysis of the conflict, the study of the cultural, social, historical features of the countries, society, communities involved in the conflict; the consent of the parties and the willingness to take responsibility for the decisions made; the legal field of official mediation; mediator impartiality and privacy.

Public mediation does not always adhere to the principle of the independence of the mediator, especially in cases where States or international organizations act as mediators. It is also difficult to make the process confidential, especially in the current development of information technology. As mediation is a professional activity, it should be ensured by experienced, trained mediators and professional teams. The issue of resource support for mediators' activities, which can be solved partly with the support of the international community, is also urgent. When attracting external funding, it is important to evaluate this opportunity in relation to the risk of donor exposure to the process design and possible solutions.

A thorough analysis of the conflict situation both within and around the country and the development of a conflict resolution strategy using various reconciliation procedures are important.

It is necessary to coordinate activities both within the same procedure and the process as a whole. In general, mediation as a method of resolving the conflict in Ukraine certainly takes place and its application will allow to change the dynamics of development and resolution of the situation in the direction of stabilization and reconciliation of interests of participants.

\section{References}

1. Emelyanko, L.M. (2003). Konfliktolohiia [Conflictology]. Kyiv: KNEU [in Ukrainian].

2. Vinoslavskaya, O.V. (2005). Psykholohiia [Psychology]. Kyiv: INCOS [in Ukrainian].

3. Kalinkina, I.V. (2009). Tvorchist yak variant sublimatsii konfliktu [Creativity as a variant of the sublimation of conflict]. Zbirnyk statei «Psykhosemantyka» -Collection of articles "Psychosemantics", 50, 14-19.

4. Orban-Lembrick, L.E. (2003). Psykholohiia upravlinnia [Management Psychology]. Kyiv: Akademvidav

5. Grishina, N.V. (1990). Ya y druhye. Obshchenye v proyzvodstvennom kollektyve [Me and others. Communication in the production team]. Lviv: Lenvydav

6. Prokopenko, G. 100 ydei dlia razvytyia tvorcheskoho potentsyala sotrudnykov [100 ideas for the development of employees' creative potential]. Retrieved from http://hrliga.com/

7. Anthony, C., Johnson, M., Sinfield, J., Altman, E. (2011). Kerivnytstvo innovatora: yak vyity na novykh spozhyvachiv za rakhunok sproshchennia ta zdeshevlennia produktu [Innovator's guide: how to reach new consumers by simplifying and reducing the cost of the product]. Moscow: Alpina Publishers 
8. Khudyakova, T.M. Ot nenavysty - $\mathrm{k}$ schastiu [From Hate - Fortunately]. Retrieved from http:// ukrmediation.com.ua / ua / useful_information / articles /?pid = 741 .

9. Sorochinska, T.A. (2016). Suchasna kontseptsiia filosofii osvity v Ukraini. Onovlennia zmistu, form ta metodiv navchannia i vykhovannia $\mathrm{v}$ zakladakh osvity [Modern concept of philosophy of education in Ukraine. Updating the content, forms and methods of education and training in educational institutions]. Naukovi zapysky Rivnenskoho derzhavnoho humanitarnoho universytetu - Scientific notes of Rivne State Humanities University, 13 (56), 33-36.

10. Nakaz Ministerstva sotsialnoi polityky «Pro zatverdzhennia Derzhavnoho standartu sotsialnoi posluhy poserednytstva (mediatsii)» [Order of the Ministry of Social Policy “On approval of the State standard of social mediation service (mediation)"]. Retrieved from http://zakon2.rada.gov.ua/laws/show/z1243-16.

11. Koval, P. (2016). Kontseptualni zasady profesiinoi pidhotovky studentiv vyshchykh navchalnykh zakladiv zasobamy mystetstva [Conceptual foundations of professional training of students of higher educational institutions by means of art]. Hirska shkola Ukrainskykh Karpat. Naukove fakhove vydannia z pedahohichnykh nauk - Mountain School of the Ukrainian Carpathians. Pedagogical Science, 15, 45-48.

12. Kalaur, S.N. Systema profesiinoi pidhotovky maibutnikh fakhivtsiv sotsialnoi sfery do rozviazannia konfliktiv u profesiinii diialnost [The system of professional training of future specialists in the social sphere to resolve conflicts in professional activity]: diss. ... doc. ped. sciences: 13.00.04. Ternopil National Pedagogical University

13. Rozbudova myru. Profilaktyka i vyrishennia konfliktu z vykorystanniam mediatsii: sotsialno-pedahohichnyi aspekt [Peacebuilding. Conflict prevention and resolution using mediation: a socio-pedagogical dimension] (2016). Kyiv: FOP Stetsenko V.V.

14. Pro mediatsiiu. Proekt zakonu № 2480 vid 27.03.2015 [About mediation. Draft Law No. 2480 of 27.03.2015]. Retrieved from http://w1.c1.rada.gov.ua/pls/zweb2/ webproc4_2?Id=\&pf3516=2480\&sk=9 